\title{
Pemberdayaan Tari Sanghyang Di Banjar Jangu, Desa Duda Kecamatan Selat, Kabupaten Karangasem, Bali
}

\author{
I Made Purna \\ Balai Pelestarian Nilai Budaya Bali \\ Jalan Raya Dalung Abianbase No. 107, Kuta Utara, Badung, Bali \\ E-mail: made.purna@kemdikbud.go.id
}

\begin{abstract}
Kearifan lokal yang diwadahi Tari Sanghyang di Banjar Jangu, Desa Duda, Kecamatan Selat, Kabupaten Karangasem, Bali mengandung nilai-nilai budaya nilai kemanusiaan, kebersamaan, persaudaraan, kearifan terhadap lingkungan, ketauladan. Karena itu tidak mengherankan oleh pendukungnya Tari Sanghyang telah difungsikan sebagai tari yang memiliki fungsi religius-magis, fungsi sosial, keharmonisan terhadap lingkungan alam, serta memiliki makna moral yang sederhana baik gending maupun pakaiannya yang sangat tergantung pada alam. Rumusan masalah yang dibahas dalam tulisan ini, antara lain, 1) kenapa tari Sanghyang di Banjar Jangu diberdayakan; 2) apa usaha pemberdayaan yang sudah dan yang akan dilakukan oleh masyarakat pendukungnya. Tujuan penulisan ini yaitu, 1) menghidupkan kembali Tari Sanghyang sebagai warisan budaya lokal; 2) membangkitkan suasana magis-religius; 3) Mempertahankan Tari Sanghyang sebagai salah satu Tari Wali yang harus tetap "hidup" ikut menunjang pelaksanaan upacara agama Hindu. Agar pemberdayaan Tari Sanghyang dapat optimal, dan bertaksu, maka model pemberdayaannya perlu dilakukan melaluicara structural dan kultural.
\end{abstract}

Kata Kunci : Pemberdayaan, Sanghyang, Religius-Magis, Taksu.

\section{Empowerment of Sanghyang Dance in Jangu Village of Duda Selat, Karangasem District Bali}

Local knowledge is contained in Banjar Jangu Trance Dance, Village Duda, District Strait, Karangasem, Bali containing cultural values of humanity, solidarity, fraternity, wise to the environment, representative. It is not surprising by supporters Dance Trance has functioned as a dance that has magical-religious functions, social harmony to the natural environment, and has a simple moral meaning both the musical and clothing is very dependent on nature. The problems discussed in this paper, among others, 1) why Trance Dance in Banjar Jangu empowered; 2) what empowerment efforts that have been and will be done by supporting community. The purpose of this paper, namely, 1) revive Dance Trance as local cultural heritage; 2) evoke the atmosphere of a magical-religious; 3) Dance Dance Trance one guardian must remain "live" for the implementation of the Hindu ceremony. In order for optimal Trance Dance empowerment, and bertaksu, then the model through structural and cultural empowerment.

Keywords: Empowerment, Trance, Religious-Magis, Taksu. 


\section{PENDAHULUAN}

Kearifan lokal yang mengandung nilai-nilai budya kemanusiaan, kebersamaan, persaudaraan, sikap arif terhadap lingkungan, ketauladan dan lain-lain dewsa ini sudah mulai banyak terkikis. Anggota masyarakat (terutama generasi muda) sudah banyak yang tidak percaya, jika kehidupannya dibentengi dengan tema-tema ketradisionalan. Para generasi muda lebih banyak memvisikan dan memisikan pola hidupnya dengan visi dan misi idiologi pembangunan mengedepankan pertumbuhan ekonomi, perkembangan fisik dan material dibandingkan dengan nilai-nilai spiritual dan kearifan lokal (local wisdom). Karena itu tidak mengherankan suasana kehidupan masyarakat masa kini banyak "diracuni" oleh gaya hidup modernisme dengan budaya konsumtifnya. Nilai-nilai kearifan lokal telah digeser, bahkan tidak sedikit dihilangkan atau dipunahkan oleh nilai modernitas. Benturan nilai-nilai tersebut tidak jarang membuat masyarakat mengalami krisis identitas maupun jatidirinya. Suasana kehidupan inilah yang terjadi pada masyarakat Banjar Jangu, Desa Duda, Kecamatan Selat, Kabupaten Karangasem, dimana kearifan lokal komunitasnya yang diwadahi oleh 17 (tujuh belas) Tari Sanghyang sudah ada yang mulai punah. Ke-17

Tari Sanghyang yang dimaksud, Sanghyang Dedari, Bojog, Kerek, Celeng, Memedi, Tutup, Jaran, Lelipi, Sri Putut, Kuluk, Teter, Capah, Sampat, Lesung, Sembe, Dongkang, Sele Parahu (Dwi Bambang Santoso, dkk. 2016 : 30-44) Padahal Tari Sanghyang merupakan salah satu diantara 9 (Sembilan) jenis tari tradisi Bali pada hari Rabu, 2 Desember 2015 di Windhoek, Namibia telah dikui dan ditetapkan sebagai Warisan Budaya Takbenda Indonesia oleh Unesco. Ke-9 jenis tari yang dimaksud yaitu, Tari Sanghyang, Tari Baris Upacara, Tari Rejang, Tari Topeng Sida Karya, Tari Barong, Tari Gambuh, Tari Wayang Wong, Tari Legong Kraton, dan Tari Joged Bumbung.

Adanya pengakuan dan penetetapan dari Unesco dimaksudkan dalam rangka menghidupkan kembali tari-tari tradisi diantaranya Tari Sanghyang, karena tari ini telah mengandung nilai-nilai budaya seperti nilai kemanusiaa, kebersamaan, persaudaraan, arif terhadap lingkungan, ketauladan. Tari ini pula, memililki fungsi dan makna religius-magis, keharmonisan terhadap lingkungan alam, serta social. Namun sayang jenis Tari Sanghyang tidak memiliki unsur naratif (Michael Picard, 2006 : 237), dan tidak diajarkan di dunia pendidikan seperti sekolah maupun di sanggar-sanggar seni. Demikian pula jadwal pementasannya tidak sembarang waktu dan tempat. Karena itu perlu pendekatan kebudayaan untuk pemberdayaan. Usaha-usaha pemberdayaan adalah bagaimana mengembalikan komunitas lokal yang mereka miliki untuk menjadi diri mereka sendiri kembali dengan nilai-nilai budaya lokal yang telah mereka miliki. Dengan kevakuman pementasan Tari Sanghyang beberapa tahun mulai disikapi oleh Balai Pelestarian Nilai Budaya Bali untuk mengadakan kajian tahun 2016.

Setelah Tim peneliti dari Balai Pelestarianh Nilai Budaya Bali tahun 2016 memberi informasi bahwa Tari Sanghyang sudah mendapat pengakuan dan penetapan dari Unesco, maka pada prinsipnya ingin menghidupkan kembali Tari Sanghyang yang pernah hidup di Banjar Jangu, Desa Duda. Walaupun tidak ke-17 Tari Sanghyang. Karena masyarakat Banjar Jangu ingin menyelematkan warisan leluhurnya yang diambang punah, dan mempercayai kembali adanya spirit dalam Tari Sanghyang serta dengan membangun kembali Tari Sanghyang suasana keakraban warga banjar maupun desa akan terjalin kembali. Bahkan tidak sedikit pendapat anggota masyarakat yang mengatakan bahwa, setelah lama tidak mementaskan Tari Sanghyang, maka telah terjadi wabah penyakit tanaman. Diperkirakan sejak tahun 1980-an masyarakat tidak mementaskan Tari Sanghyang. Kalaupun pernah ada pementasan setelah tahun 1980-an, pementasan itu bukan untuk kepentingan spiritual maupun magis, dan social maupun berkaitan dengan pengusiran wabah penyakit terhadap tanaman, hewan maupun manusia. Melainkan pementasan tersebut hanya kepentingan pariwisata, yang sifatnya sekuler dan ekonomi. Padahal asal-sul lahirnya Tari Sanghyang berdasarkan dua Lontar yaitu Lontar Kecacar dan Lontar Tantu Pagelaran dengan masing-masing menyebutkan sebagai berikut : 1) Lontar Kecacar disebutkan bahwa Tari Sanghyang merupakan anugrah Ida Bhatara di Gunung Agung kepada Empu Kuturan.

2) Lontar Pagelaran menyebutkan bahwa, Tari Sanghyang merupakan tari penolak penyakit kecacar dan grubug (sampar) (Gusti Agung Gd Putra, tt. 11-12). Lebih jauh disebutkan, jika musin "grubug" (penyakit sampar), pada saat mana "bhutakala" berkeliaran dimana-mana lalu dipertunjuk 
kan tarian Sanghyang dan banten caru dan Tunggul Gana. Para bhutakala sangat tertarik mendengar dan melihat tarian-tarian Sanghyang, sehingga ramai-ramau menonton, namun kemudian terkejut dan lari pontang-panting setelah melihat bhatara Gana ada di sana. Bhatara Gana yang dikenal dengan nama lain adalah Wighnecwara (yang artinya Dewa dari halangan) adalah penghalau kejahatan dan musuh dari segala bencana.

Dengan demikian, sebelum dunia kesehatan maju seperti sekarang, dengan mementaskan Tari Sanghyang bukan tujuannya sebatas sebagai alat upacara untuk berhubungan dengan Maha Pencipta. Namun lebih kompleks yaitu, menolak bencana dan penyakit, mewujudkan keharmonisan dan keseimbangan hubungan antara manusia dengan manusia (resolusi konflik) dan hubungan harmonis dan seimbangan antara manusia dengan alam lingkungan dengan konsep diterminisme, penguatan identitas dan jati diri masyarakat pendukungnya.

Dari uraian tersebut di atas maka dapat dirumuskan permasalah sebagai berikut : 1) Kenapa Tari Sanghyang di Banjar Jangu, Desa Duda, perlu diberdayakan; 2) Apa usaha pemberdayaan yang sudah dan akan dilakukan oleh masyarakat Banjar Jangu, Desa Duda. Kecamatan Selat, Kabupaten Karangasem.

Tujuan dari penulisan artikel ini antara lain : 1)menghidupkan kembali Tari Sanghyang sebagai warisan budaya lokal, karena warisan budaya Tari Sanghyang sudah dikenal di kancah internasional.

2) membangkitkan suasana daerah dengan spirit dan magis, karena taksu Bali ada pada Tari Sanghyang. 3) Mempertahankan Tari Sanghyang sebagai salah satu tari Wali yang harus tetap "hidup" dalam pelaksanaan upacara dalam Agama Hindu.

\section{KAJIAN PUSTAKA}

Pertanyaan yang paling mendasar yang selalu muncul dibenak peneliti, maupun pemerintah, terhadap tujuan mengadakan pelestarian dengan penggalian, perlindungan, pengembangan dan pemanfaatnya pada seni tradisi umumnya dan Tari Sanghyang khususnya? Tentu jawaban singkat yang sering dikemukakan oleh peneliti, karena Tari Tradisi tersebut memiliki fungsi dan makna bagi kehidupan pendukungnya. Karena itu, tidak mengherankan kalau penelitian ini teori besarnya menggunakan Teori Fungsionalisme B. Malinowski (dalam Koentjraningrat, 1997). Lebih jauh beliau mengemukakan segala aktivitas (unsur) kebudayaan pada hakekatnya untuk memenuhi kebutuhan dasar manusia. Oleh karena itu, setiap pola adat kebiasaan merupakan fungsi dasar dalam kebudayaan. Masyarakat dapat dikatakan sebagai system social yang di dalamnya berdiri sendiri atas bagian-bagian yang saling berhubungan dalam rangka pemenuhan kebutuhan dasarnya baik kebutuhan dasar primer maupun sekunder. Pementasan Tari Sanghyang merupakan bagian kebutuhan dasar sekunder dari manusia. Tari ini termasuk tari wali (sakral) dan klasik. Jika dibandingkan dengan kehidupan tari wali klasik lainnya, tari ini telah memiliki karakter dan fungsi yang lebih khas dan relatif kurang popular. Karena tujuan pementasanya bukan untuk menghibur. Namun lebih ditujukan untuk pemenuhan kebutuhan dasar religius-magis. Karena itu tidak mengherankan kalau tari ini dijadikan medium kegiatan ritual-magis untuk mengusir maupun nyomiang para Bhuta Kala. Kekuatan Bhuta Kala dalam tradisi Agama Hindu di Bali selalu menjadi perhitungan dalam beryadnya. Umat Hindu harus bijaksana dalam menghadapi Bhuta Kala. Orang Bali yang beragama Hindu harus melibatkan para Bhutakala. Karena tanpa bhutakala maka yadnya tidak akan selesai dengan sempurna. Pada umumnya di Bali dan di Banjar Jangu khususnya, Bhuta Kala bisa menyebabkan timbulnya wabah penyakit tanaman, khewan dan manusia, serta ketidak-harmonisan hubungan antar warga desa.

Pada kondisi seperti itu manusia mengalami krisis. Karena itu tidak mengherankan kalau manusia pada saat seperti itu menghadirkan sesuatu yang sifatnya transeden, dan semua itu dilakukan melalui upacara (Murdiyati, 2009:1-3). Upacara dengan sarana kesenian, namun jenis kesenian tetap bertolak dari makna upacara itu sendiri. Ketika terjadi krisis bersama, manusia menghadirkan kekuatan kosmos untuk mengatasi krisis itu. Konsep kesatuan kosmos hanya dapat diperoleh melalui sistem kepercayaan. Karena itu pengetahuan tentang kosmologi kepercayaan, terutama para generasi tua sangat diutamakan. Upacara yang lebih menonjolkan nilai religius-magis yang dimaksudkan dalam situasi yang sering dilakukan secara mentradisi di Banjar 
Jangu dengan menyelenggarakan pementasan Tari Sanghyang. Karena dengan pementasan Tari Sanghyang jaman terdahulu akan menjawab krisis yang dirasakan masyarakat.

Untuk memperkuat pernyataan di atas akan dikemukakan pula pendapat dari Redcliffe Brown (Kaplan dan Manner, 1999), yang mengemukakan bahwa, eksistensi upacara keagamaan yang memiliki kaitan dan memberikan sumbangan yang besar terhadap kerekatan social. Dengan kembali diberdayakan pementasan Tari Sanghyang di Banjar Jangu, anggota masyarakat bisa hidup berdampingan kembali seperti sebelumnya. Teori fungsional tersebut diatas dilengkapi dengan teori Semiotika dari Marco de Marinis (dalam Geertz, 1992 :5), yang mengatakan bahwa kebudayaan pada hakikatnya merupakan sebuah konsep semiotic atau tentang tanda. Tanda memiliki dua aspek yaitu yang bisa ditangkap oleh panca indera, dan tanda yang dapat dipersepsikan sebagai tanda yang memiliki makna. (dalam Nuryahman, dkk. 2015 :8).

Kajian tentang Tari Sanghyang cukup banyak, diantaranya yang dilakukan oleh Tim Peneliti dari Proyek Pengembangan Kesenian Bali, Direktorat Jenderal Kebudayaan, Depdikbud pada tahun 1984/1985. Pada tahun 1998/1999 oleh I Dewa Gede Raka, dkk., dengan judul laporan penelitian : Deskripsi Tari Sanghyang Desa Jangu Karangasem, Bali. Pada tahun 2002 oleh Tim Peneliti dari Dinas Kebudayaan Provinsi Bali dengan judul: Hasil Penelitian Tari Sanghyang di Banjar Jangu, Desa Duda, Kecamatan Delat, Kabupaten Karangasem. Ketiga jenis Penelitian ini hanya mesdeskripsikan atau mencatat apa adanya tentang Tari Sanghyang yang tumbuh di Banjar Jangu. Belum mengulas tentang fungsi, makna, apalagi langkah pemberdayaan.

Penelitian perseorangan yang pernah dilakukan oleh Made Pantja pada tahun 1994, dengan judul Tesis S-2 : "Upacara Sanghyang Dedari di Desa Celuk, Kecamatan Sukawati, Kabupaten Gianyar, Provinsi Bali". Tesis ini belum diterbitkan. Penelitian-penelitian maupun penulisan tentang Tari Sanghyang sebelumnya juga sudah pernah dilakukan oleh J. Belo pada tahun 1960; Lovric pada tahun 1987; O' Neill pada tahun 1978; Suryani dan Jensen pada tahun 1993 (Lihat di Michael Picard, 2006 :227). Catatan kecil juga pernah dilakukan oleh I Gusti Agung Putra, dalam rangka pengelompokkan jenis-jenis tari-tari tradisi di Bali pada buku Cudamani (tanpa tahun).

\section{FUNGSI DAN MAKNA TARI SAN- GHYANG BAGI MASYARAKAT BANJAR JANGU}

\section{A. Fungsi Religius-Magis}

Tari Sanghyang ditemukan hampir di seluruh Kabupaten di Bali. Akan tetapi yang paling banyak ditemukan di Kabupaten Karangasem, tepatnya di Banjar Jangu. Latar belakang lahirnya Tari Sanghyang di seluruh Bali pada umumnya disebabkan penduduk pulau Bali adalah beragama Hindu dan dalam agama Hindu wajib melaksanakan Panca Yadnya. Satu diantara Panca Yadnya, yaitu pada upacara Bhuta Yadnya harus menyuguhkan tari wali berupa Tari Sanghyang. Pementasan tari ini, banyak dilakukan pada bulan Maret (sasih Kesanga), karena bulan Maret banyak melakukan upacara Bhuta Yadnya seperti ritual Pecaruan, Ngutang Pakelem, Nangkluk Mrana. Dalam batas tertentu, merupakan tanda atau jejak kemungkinan sebagai fenomena yang berkaitan dengan keberadaan Tari Sanghyang. Walaupun Tari Sanghyang merupakan sisa-sisa dari kebudayaan pra- Hindu, dan dapat digolongkan salah satu ciri tradisi kecil serta dapat dibuktikan atau dicirikan adanya trance (kerawuhan) (Panji, 1979:38). Karena sampai saat ini penari pada tarian Sanghyang penarinya kemasukan Hyang (spirit) yang menyebabkan mereka tidak sadarkan diri. Kata Hyang sangat berkaitan dengan spiritual dan magis. Karena itu tidak mengherankan, bahwa penari Sanghyang, jika sudah trance, kekuatan tenaga yang ada pada saat menari bisa melebihi dari kekuatan manusia. Karena ada kekuatan di luar kekuatan manusia inilah Tari Sanghyang difungsikan oleh masyarakat Banjar Jangu sebagai tari mengandung religius-magis.

Berdasarkan hasil wawancara selama di lapangan (Bapak Made Dangin), bahwa pementasan Tari Sanghyang di Banjar Jangu dipentaskan pada bulan Maret. Setelah Upacara Usaba Dodol. Diceritakan pada jaman dahulu (cerita mitos dari mulut ke mulut) di Banjar Jangu pernah dilanda musibah besar yang melanda semua jenis tanaman sakit akibat diserang hama. Tentu saja, penduduk yang menggantungkan hidup dari pertanian dan perkebunan jadi menderita. Karena tidak lagi memiliki 
sumber penghasilan. Penduduk mengalami krisis mental dan pangan.

Untuk menghentikan serangan hama itu, penduduk kemudian membuat Upacara Mecaru. Harapannya dengan Mecaru ini, para Bhuta Kala tidak lagi mengganggu tanaman mereka. Diyakini pula, para Bhuta Kala itu berkaitan dengan Raja Wabah yang bernama I Dewa Gede Mecaling, berasal dari pulau Nusa Penida.

Dikisahkan Raja Wabah pada waktu-waktu tertentu selalu pergi ke Pura Besakih mengajukan permohonan "nunas atma" (tumbal) untuk dijadikan pengikut. Pada saat Raja Wabah ini pergi ke Pura Besakih. Diyakini pula selalu diikuti oleh Bhuta Kala yang menyebarkan berbagai macam penyakit.

Mula-mula Upacara Mecaru ini diperkirakan cukup dilaksanakan secara sederhana dan dipusatkan di banjar-banjar. Namun nyatanya, penduduk seusai Mecaru masih merasakan ancaman dari para Bhuta Kala. Dikisahkan kemudian penduduk memutuskan untuk mengadakan Upacara Mecaru yang lebih besar dipusatkan di Desa Adat.

Dari peristiwa Mecaru inilah diduga awal kelahiran Tari Sanghyang, yaitu merujuk pada kisah, pada suatu ketika, sehabis dilaksanakan Upacara Mecaru, yaitu diwujudkan dengan pembagian hebatan/olahan daging anjing Bangbungkem (anjing yang bulunya merah dan moncongnya hitam), pada sore harinya, seperti biasa diadakan Upacara tek-tek prus, yaitu upacara mengaturkan hebatan dengan alas daun keladi di depan rumah.

Pada saat mengaturkan sajen tersebut penduduk melengkapi dirinya dengan obor terbuat dari daun kelapa kering disertai Kesuna Jangu, Sirih, Minyak dan sepotong bambu. Pelaksanaan Upacara Tek-Tek Prus ini adalah kegiatan mengelilingi sudut-sudut pekarangan rumah maupun banjar dengan memukul-mukul bambu disertai menyeburkan Kesuna Jangu, Minyak dan Sirih. Jadi, dari suara tek-tek akibat bambu dipukul dan semburan Kesuna Jangu, Sirih bercampur Minyak inilah asal nama Tek-Tek Prus berasal. Semburan tersebut menimbulkan suara "prus" yang dilanjutkan dengan mengucapkan doa "Megedi Bhuta Kala Mulihang Sari" (Pergilah Bhuta Kala, kembalikan rejeki). Setelah kegiatan Tek-Tek Prus ini selesai dilaksanakan di pekarangan rumah, penduduk kemudian berkumpul di halaman banjar dengan membawa sisa obornya. Lalu di halaman banjar diadakan kegiatan lemparlemparan obor atau disebut Perang Bobok.

Penduduk Banjar Jangu meyakini, disaat pelaksanaan Upacara Tek-Tek Prus, beberapa orang akan jatuh pingsan disebabkan mereka melihat Bhuta Kala. Bhuta Kala itu ada yang berbentuk sebagai kuda, babi, kera dan bentuk lainnya seperti nama nama jenis Tari Sanghyang yang lahir di Banjar Jangu. Setelah sadar dari pingsan, orang-orang yang telah melihat Bhuta Kala akan meniru tingkah Bhuta Kala tersebut. Lalu penduduk secara simbolik melakukan pengusiran.

Sebagai bandingan, berdasarkan penelitian yang dilakukan oleh Wayan Sudarma, (2015), di Desa Adat Sidetapa, bahwa Tari Sanghyang Gandrung adalah salah satu tari sakral yang pementasannya masih dilaksanakan sampai sekarang. Tari Sanghyang Gandrung terdiri dari dua kata yakni, kata Sanghyang yang memiliki arti mepinunas (memohon), dan Gandrung berarti kala (membawa pengaruh negatif). Kala sesungguhnya berarti waktu, namun dalam konteks tari Sanghyang Gandrung diyakini memiliki arti tersendiri yaitu pengaruh negative. Lebih lanjut dikatakan bahwa asal mula terbentuknya tari sakral Sanghyang Gandrung dapat disimak dari alur kisah masyarakat Sidetapa. Disebutkan bahwa pada tahun 785 , masyarakat Sidetapa secara serempak mengalami penyakit yang susah disembuhkan. Berbagai cara pengobatan telah dilakukan oleh masyarakat, namun tanda-tanda untuk sembuh tidak kunjung datang. Kondisi kesehatan masyarakat secara keseluruhan semakin menurun, sehingga para pengelingsir (leluhur/tetua) mereka mengalami kebingungan. Merasa kehabisan akal untuk mengatasi masalah ini, pengelingsir mereka melakukan pertapaan di Pura Desa Bale Agung Sidetapa untuk memohon petunjuk Ida Sanghyang Widhi (Tuhan Yang Maha Esa). Selama pertapaan berlangsung, akhirnya beliau mendapatkan pewisik (wahyu) dari Hyang Kuasa agar masyarakat setempat menciptakan sebuah tarian yang dinamakan Tari Sanghyang Gandrung. Tujuannya adalah untuk memberi upah berupa hiburan kepada Sang Bhuta Kala (mahluk halus) agar tidak mengganggu masyarakat dalam kesehariannya baik berupa penyakit maupun bahaya lainnya. 
Sejalan dengan penelitian di atas, Ketut Sudharma Putra, (20015) juga mengadakan penelitian tentang Tari Sanghyang Janger Mabobor. Ternyata hasil penelitian tentang Tari Sanghyang Janger Mabobor juga memperlihatkan bahwa tari Sanghyang dapat dipakai sarana untuk penyembuhan penyakit dan menghilangkan kekotoran dan mala petaka yang menimpa manusia maupun alam semesta. Sarana penyembuhan pada tarian ini memakai api. Sarana api dalam tarian Sanghyang juga menjadi ciri khasnya. Karena itu tidak mengherankan kalau orang luar menyebutnya sebagai tari api. Karena salah satu sarana pokonya adalah api atau asap. Api oleh masyarakat Hindu di Bali dianggap memiliki kekuatan magis yang dapat melindungi warga masyarakat dari serangan roh-roh jahat, atau secara spiritual api dapat menghubungkan antara manusia dengan Tuhan, (Dibia, 1999/2000:13).

Dalam lontar Kacacar sebagai lontar anugrah dari Bhatara dari Gunung Agung yang diberikan kepada Empu Kuturan, ada menyebeutkan bahwa tari Sanghyang merupakan tari penolak bala ( penyakit cacar) dan penyakit sampar (Pandji, 1979).

Bila dikaitkan dengan uraian Dr. Claire Holt dalam bukunya "Art in Indonesia" yang antara lain mengatakan: The inhabitants have danced ever since they discovered the of rhythnuc movements paranging excitement. Wheter of desire, fear or joy The inherent "magie" of dance is its generation of witality in both the dancer and the spectator. The dance is a liberating incantations like hymns anda prayer. Lt accompones celehration of all important aspeets of life not the least death (I Dewa Gede Raka, 1998/1999)

Diterjemahkan secara bebas oleh penulis "Penduduk (Indonesia) telah menari sejak mereka mengetahui rahasia tentang gerakan-gerakan ritmis yang tercetus dari rasa bergelora, baik karena keinginan, ketakutan maupun kegembiraan. Kekuatan magis yang melekat daripada tari itu merupakan pancaran dalam bentuk kehidupan baik pada penari maupun penonton. Tari itu adalah mantra yang dilepaskan sama halnya dengan lagu-lagu suci dan pujaan-pujaan. Ia mengiringi segi-segi penghidupan yang penting, dan tidak pula kurang artinya dalam hal kematian", maka Tari Sanghyang secara penampilan memang menunjukkan ciri-ciri seperti yang diuraikan oleh Dr. Claire Holt.
Dengan kata lain, seperti keyakinan penduduk di Desa Jangu, tari ini sudah ada sejak dahulu kala, sejak manusia di desa tersebut mengetahui adanya gerakan-gerakan ritmis yang dimotivasi oleh ketakutan terhadap wabah penyakit.Tari Sanghyang diyakini adalah sebagai kegiatan yang memiliki kekuatan layaknya mantra, yang dicetuskan dengan nyanyian-nyanyian magis dengan harapan wabah penyakit akan pergi dan kehidupan pulih kembali.

Tari Sanghyang di Banjar Jangu pada mulanya hanya dipentaskan di malam hari dengan maksud untuk gampang medapatkan aura magis dari para dewa yang berstana di Pura atau pelinggih Ida Bhetara Gede yang ada di tengah Banjar Jangu. Biasanya, tarian ini dipentaskan pada bulan Maret (Sasih Kesanga) atau bila terjadi epidemic. Kini, tari ini dapat pula dipentaskan dan ditonton pada hari-hari biasa asalkan hujan tidak turun. Apabila hujan turun tarian ini tidak dapat dipentaskan.

Penari Sanghyang (bukan sebagai penari biasa), sebab penari Sanghyang akan mengalami Kerawuhan (Kesurupan/Trance), namun di Banjar Jangu tidak ditemukan persyaratan bersifat khusus bagi penarinya, kecuali persiapan wajar, seperti pembersihan diri (mandi dan dalam kondisi sehat), kemudian mengenai tata riasnya dilakukan lazimnya seorang penari Sanghyang atau dirias sesuai dengan jenis tari yang akan dimainkan.

Untuk pementasan, Tari Sanghyang memerlukan bantuan nyanyian untuk menghadirkan kekuatan Hyang. Juru gending biasanya yang dibawakan oleh sekelompok penyanyi (disebut : Tukang Gending, Sekeha Tandak), biasanya berjumlah 10 sampai 15 orang, kadangkala jumlah penyanyi untuk beberapa jenis Tari Sanghyang menuntut jumlah penyanyi dalam jumlah tertentu. Namun, secara umum jumlah itu tidak ditentukan secara ketat.

Selain itu, untuk pementasan Tari Sanghyang dilengkapi pula persembahan sesajen. Melengkapi dengan sesajen dimaksudkan untuk memudahkan mendatangi Hyang. Secara umum sajen itu berupa : Canang Raka, Canang Sari, Saagan dan Daksina. Sedangkan untuk busana, Tari Sanghyang relative tidak membutuhkan busana yang megah. Tata rias Tari Sanghyang relative sederhana, dirias sesuai dengan jenis Sanghyang yang akan dimainkan. Bahan perlengkapan rias berasal dari alam sekitar. 
Misalnya, untuk Tari Sanghyang yang medium trancenya benda, yang diperlukan adalah beberapa jenis pohon yang tumbuh di sekitar desa seperti Sanghyang Teter memerlukan pohon teter, Sanghyang Kerek property yang diperlukan kayu api yang ada di sekitar Banjar Jangu.

Mengenai tata panggung, Tari Sanghyang membutuhkan halaman. Biasanya halaman Pura sebagai media yang paling mudah untuk menghadirkan Hyang. Luas penggung disesuaikan dengan energinitas Sanghyang itu sendiri. Seperti Sanghyang Jaran, tentulah memerlukan luas panggung karena geraknya lebih luas. Perlengkapan lain adalah altar. Altar ini pun dibuat dengan sederhana, mirip sanggah semi permanen.

Kekhasan Tari Sanghyang dibandingkan dengan tari-tarian lain di Bali adalah pada kandungan kesurupannya, pada unsur trance. Inilah perbedaan menonjol ciri keberadaan tampilan Tari Sanghyang dengan jenis tari wali klasik sakral seperti tari Rejang dan Baris Upacara di Bali. Karena itu, secara umum, pementasan Tari Sanghyang amat memperhitungkan komposisi ruang dan arah mata angin.

Komposisi ruang menentukan keyakinan penari dan penonton. Pementasan biasanya dilakukan di halaman Pura, arah Timur halaman Pura adalah wilayah suci, tempat dibangun sebuah altar. Arah Timur maupun Utara, sebagai Kepala dalam komposisi ruang pementasan, diyakini sebagai tempat roh-roh yang akan diundang untuk turun menari. Dengan demikian, komposisi ruang, posisi letak altar maupun penari memiliki kaitan andil dalam keberhasilan pementasan secara keseluruhan. Semua itu sebetulnya bisa disebut pengkondisian untuk medium kerawuhan/kerasukan (trance). Di Banjar Jangu, medium untuk kesurupan adalah manusia dan benda. Khusus untuk benda, seperti pohon teter, pohon singkong, alang-alang, daun enau yang masih muda ( $a m b u)$ dan pohon dapdap dapat dijadikan medium kesurupan, dan harus dicari dengan prilaku khusus, disebut "piit/pingit" atau dilakoni dengan sikap dan prilaku dirahasiakan. Tegasnya, ketika mencari benda-benda untuk medium kerauhan tersebut, orang lain tidak boleh tahu. Tanda bahwa benda-benda tersebut memiliki kekuatan kesurupan (nadi) kepengaruhannya pada yang memegang, namun hanya sebatas tangan.
Proses selanjutnya, setelah tempat pementasan disiapkan adalah proses pengasapan terhadap penari. Proses pengasapan (ngukup) dilakukan di hadapan altar dengan pedupaan. Untuk beberapa jenis Sanghyang, seperti Sanghyang Sri Putut menggunakan dua buah pedupaan. Proses ini amat penting karena merupakan bagian kosentrasi mengundang roh.

Seorang penari menunduk (untuk medium benda diletakan di atasnya dengan jarak tertentu) di atas pedupaan yang telah berasap. Pada saat itu, penari mengatupkan matanya untuk berkosentrasi, memohon agar roh yang dikehendaki memasuki dirinya, proses kosentrasi ini dibantu dengan nyanyian. Nyanyian dinyanyikan dengan irama tertentu, dengan syair yang sebenarnya sederhana. Fungsi nyanyian ini amat menentukan, apabila syairnya tidak lengkap, proses trance tidak akan tercapai.

Tanda penari telah dimasuki roh atau telah pada fase trance/kesurupan/kerawuhan, adalah ketika si penari jatuh dan lupa sejenak, setelah itu bangkit dan bertingkah laku atau menari dengan roh yang diharapkan datang (untuk benda, apabila benda itu telah bergerak menirukan gerak mahluk hidup). Apakah menghadirkan Dedari, Bojog, Kerek, Celeng, Memedi, Tutup, Jaran Gading, Lelipi, Sri Putut, Kuluk, Teter, Capah, Sampat, Sembe, Lesung, Dongkang, Saab dan Ceeng. Lama penari menari atau disebut menadi (menari dalam kondisi kesurupan/trance) tidak dapat ditentukan, tergantung dari daya tahan batin si penari menahan roh dalam tubuhnya. Apabila tarian tersebut berlangsung terlalu lama, maka untuk menyadarkan si penari atau membebaskannya dari roh dengan cara memercikan air atau air suci.

Tetapi tidak semua Tarian Sanghyang dapat dihentikan aktivitasnya dengan percikan air. Untuk Sanghyang Dedari, tarian ini berhenti hanya apabila roh yang memasuki si penari menghendaki tariannya berhenti. Umumnya, kondisi semua penari/pelaku seusai menarikan Sanghyang dalam kondisi tubuh menunjukan tanda kelelahan.

Untuk memperkuat fungsi Tari Sanghyang sebagai tari persembahan terhadap para Hyang yang mengandung religius magis dapat disimak dari isi Lontar Tantu Pagelaran, khususnya pada bagian yang menyinggung soal keberadaan Sanghyang 
Dedari. Dikisahkan, pada saat Dewa Siwa yang hendak mensucikan Sanghyang Pancakosika, yaitu Kosika, Garga, Metri, Kusya dan Pertanjala. Dewa Siwa menugaskan istrinya, Dewi Uma, untuk mencari air susu Lembu Hitam (empehan). Pencarian air susu Lembu Hitam ini ternyata tidaklah mudah, walaupun dengan segala daya upaya Dewi Uma tidak mendapatkan air susu tersebut.

Dewa Siwa yang mengetahui keadaan itu lalu mengubah Lembu Mandini menjadi Lembu Hitam dan Siwa sendiri menjadi penggembalanya. Kemudian dikisahkan, Dewi Uma dalam segala daya upayanya itu akhirnya melihat keberadaan Lembu Hitam tersebut. Dikisahkan kemudian, ia meminta air susu Lembu Hitam itu kepada si Pengembala. Tetapi si Pengembala tidak memberikan air susu tersebut, kecuali Dewi Uma bersedia melakukan hubungan badan dengannya.

Dewi Uma sadar bila ini adalah ulah Dewa Siwa. Dewi Uma pun bersedia melakukan hubungan badan dengan si pengembala. Tatkala itu terjadi, air mani Dewa Siwa diceritakan berjatuhan dan secara ajaib berubah menjadi Widiadara dan Widiadari, salah satunya yang tercantik dikenal sebagai Diah Kintamani. Lalu oleh Dewa Siwa seluruh Widiadara dan Widiadari ini dijadikan penari di sorga.

Kisah tersebut diyakini berkaitan dengan keberadaan Tari Sanghyang Dedari. Selanjutnya, dikisahkan pula, pada waktu terjadi epidemi penyakit sampar, disaat bhutakala berkeliaran di tengah kehidupan masyarakat. Tari Sanghyang selayaknya dipertunjukan dengan dilengkapi Sajen Pecaruan dan Tunggul Ganakumara. Mengapa demikian, karena diyakini para Bhutakala amat senang menonton pementasan Tari Sanghyang dan mereka akan datang beramai-ramai menontonnya. Tetapi biasanya, para Bhuta Kala itu akan terkejut dan lari pontang-panting setelah melihat kehadiran Dewa Gunakumara diantara keindahan tarian Sanghyang. Dewa Ganakumara diyakini sebagai Dewa Wigheswara, yaitu Dewa halangan, penghalau musuh dan bencana.

\section{B. Fungsi Keharmonisan Terhadap Lingkungan Alam}

Untuk mencapai keharmonisan, kedamaian dan kesejahteraan yang ideal didalam kehidupan manusia, manusia tidak cukup dipuasi oleh kebutuhan dasar yang disimboli dengan pementasan tari Sanghyang sebagai tari persembahan. Akan tetapi sangat signifikan menjalin keharmonisan dengan lingkungan alam. Konsep hubungan antara manusia dengan lingkungan alam telah dikupas oleh $\mathrm{F}$. Ratsel melalui konsep antropogeographie dan tentang ekologi budaya yang dikemukakan oleh Julian Steward melalui konsep possiblisme. Antropogeographie yang berorientasi pada paham diterminisme lingkungan. Dinyatakan bahwa, manusia dalam konsep tersebut dipandang sebagai mahluk dinamis yang militasnya sangat ditentukan oleh kondisi alam yang ada dipermukaan bumi. Sehubunaan dengan itu, lingkungan alam akan berfungsi sebagai penentu yang akan menentukan kehidupan berikutnya. Diterminisme lingkungan yang melihat bahwa, populasi manusia dengan perkembangan budayanya sangat ditentukan oleh lingkungan alamnya. Namun secara bertahap sudah mulai ditinggalkan, mengingat dalam kenyataannya yang lebih berperan dalam lingkungan tersebut adalah manusia. Hal tersebut tampak dari pemikiran-pemikiran dalam aliran possibilisme yang dikembanakan oleh E.C Semple maupun Paul Vidal De La Blache. Lingkungan alam menurutnva tidak merupakan faktor dominan yang menentukan kegiatan manusia. Faktor yang menentukan menurut pandangan tersebut adalah proses produksi yang dipilih oleh manusia dan berasal dari kemungkinan-kemungkinan yang diberikan oleh alam baik berupa tanah, iklim, dan ruang yang ada di suatu daerah. Sehubunaan dengan itu meskipun lingkungan dapat mempengaruhi pola-pola kebudayaan dengan menghadirkan berbagai kendala. Akan tetapi lingkungan sendiri tidak akan bisa menciptakan fenomena-fenomena tersebut. Manusia telah dipandang sebagai faktor aktif terhadap lingkungannya. Sebaliknya, lingkungan alam banyak memberikan kemungkinan terhadap perkembangan kehidupan manusia. Pandangan dari possibilisme tersebut pada hakekatnya sesuai dengan pendekatan ekologi budaya yang dikemukakan oleh Julian Steward (dalam Kaplan dan Manner, 1999:105). Berkenaan dengan ekologi budaya, Steward mengungkapkan bahwa, hubungan antara kebudayaan dan lingkungannya secara fungsional sudah terlihat, begitu juga dengan hubungan pola-pola kehidupan dengan organisme lingkungan terlihat dengan jelas. 
Adanya hubungan tersebut menunjukkan bahwa pengaruh keadaan lingkungan alam sangat mendalam terhadap diri manusia. Demikian sebaliknya manusia akan mengembangkan sistem nilai tertentu sesuai dengan lingkungannya berada. Dalam pandangan yang senada Koentjaraningrat (1990:48), menyatakan bahwa, ekologi budaya dapat diartikan sebagai pengaruh timbal balik lingkungan alam yang telah diubah oleh kebudayaan manusia terhadap kehidupan dan tingkah laku manusia pada suatu lokasi tertentu di muka bumi. Berkenaan dengan itu dapat dikatakan bahwa kebudayaan merupakan suatu proses adaptasi dari manusia dalam berinteraksi dengan lingkungannya. Demikian juga sebaliknya keberadaan suatu lingkungan akan dapat mendorong manusia untuk menciptakan kebudayaan. Sanderson, (2000:44), mengatakan bahwa, kebudayaan sendiri merupakan totalitas kompleks yang memuat tiga rangkaian gejala, yakni teknologi yang ditemukan oleh manusia guna beradaptasi dengan lingkungannya, pola perilaku yang diikuti para individu sebagai anggota masyarakat atau sistem sosial, dan berbagai kepercayaan, nilai dan aturan sebagai pedoman bagi hubungan mereka satu sama lainnya dan juga dengan lingkungannya. Perkembangan kebudayaan suatu masyarakat dari proses adaptasinya tidak terlepas dari penafsiran dan pengetahuan dari masyarakat terhadap lingkungan. Dalam artian tersebut, keseluruhan dari pengetahuan manusia sebagai mahluk sosial yang dapat digunakan untuk memahami dan menginterpretasikan lingkungan alam dan sosial akan mendorong terwujudnya kelakuan. Dengan demikian, kebudayaan merupakan serangkaian aturan-aturan, petunjuk-petunjuk, resep-resep, rencana dan strategi atas serangkaian model-model kognitif yang dipergunakan sesuai dengan lingkungan yang dihadapinya.

Berkenaan dengan proses adaptasi yang dilakukan oleh manusia dalam berhadapan dengan lingkungannya, merupakan suatu proses teknologi dan juga proses sosial. Sebagai proses teknologi mengandung arti bahwa ketika manusia menghadapi tantangan, maka ia akan berusaha untuk memperbaiki institusi atau struktur sosial yang dimilikinva. Dengan demikian, melalui suatu proses adaptasi manusia akan mencoba untuk memperoleh peningkatan kebebasan dari adanya kendala atau hambatan yang bersumber dari alam.
Pendekatan tentang adaptasi manusia terhadap lingkungannya, juga dikemukakan oleh Soemarwotto (1997:48), menurutnya dinyatakan bahwa, "adanya perubahan terhadap lingkungan baik yang terjadi dengan cepat maupun lambat orang akan berusaha mengadaptasikan dirinva dengan perubahan itu, kendatipun adakalanya orang tidak berhasil mengadaptasi perubahan itu sebagai menghasilkan sifat (prilaku) yang tidak sesuai dengan lingkungannya". Jelaslah dapat dikatakan, jika lingkungan (habitat) mengalami perubahan secara langsung, maupun tidak langsung akan mempengaruhi penghuninya baik manusia maupun binatang.

Pendekatan ekologi budaya dalam penulisan ini akan dipergunakan untuk menelaah tentang adaptasi Tari Sanghyang dengan lingkungan yang berubah, sehingga tetap dapat bertahan hidup dengan teknologi atau cara yang dimilikinya. Demikian pula sebaliknya dalam pendekatan ini juga akan digunakan untuk menelaah tempat pertunjukkan Tari Sanghyang dalam membentuk pola tindakan dari suatu masyarakat.

Dari pendapat masyarakat yang dikemukakan pada permasalahan tersebut di atas, pada hakekatnya sangat berkaitan dengan pengelolaan dan pemanfaatan terhadap lingkungan. Terlahirnya jenis-jenis tari Sanghyang juga sangat berkaitan dengan ekologi yang ditempati oleh penduduk Banjar Jangu, yang kehidupannya sangat didominasi dengan kehidupan pertanian sawah maupun kebun sangat mempengaruhi aktivitas masyarakat baik dari aspek kepercayaan, sosial, dll.

Hasil wawancara selama di lapangan dengan beberapa nara sumber yang telah diberi pengetahuan dari para orang tua seperti nenek maupun kakeknya, yang mengemukan bahwa :" Dulu semasih nenek gadis kecil, banyak teman-teman bermain kesini (maksudnya di rumahnya sendiri), mereka sangat baik dan akrab; mengapa sekarang mereka tidak pernah ada yang datang lagi? Teman-teman yang ditafsirkan oleh pewaris sekarang itu yaitu, Lemputu, Kemangmang, dan Tangan-tangan yang baik-baik sekali”. Apa yang dikemukakan oleh para tetua itu sungguh menarik untuk dijadikan acuan bahwa pada jamannya (sekitar seratus tahun yang lalu) tentu ada dialog komunikasi yang akrab tentang kehidupan lingkungan di Desa Jangu antara manusia, alam dan 
kekuatan yang baik di sekitar Banjar Jangu. Lingkungan ketika itu dapat kita bayangkan kedamainya, keakrabannya, keharmonisannya. Sampai saat ini cerita itu masih dipercaya. Walaupun hanya dalam cerita dari mulut-kemulut atau cerita lisan ke lisan. Lempupu yang dimaksudkan berupa benda bagian manusia hanya kaki atau pahanya saja. Kemangmang itu berupa kepala manusia lengkap. Sedangkan tangan-tangan yang dimaksudkan sebuah lengan manusia yang utuh.

Para pewaris yang masih hidup dewasa sekarang telah menyimpulkan bahwa, "Berkomunikasi dengan lingkungan alam (termasuk isinya yang bisa dilihat dengan kasat mata maupun yang tidak bisa dilihat, namun dapat dirasakan), di jaman para tetua yang diperkirakan seratus tahun yang lalu, masih sangat mudah, dengan kekuatan-kekuatan alam lingkungan. Dengan para makhluk yang sulit dipahami secara rasio, komunikasi sangat harmonis, karena diantara kehidupan sesame saling tidak mengganggu dan malahan saling membutuhkan bantu-membantu dengan manusia. Kehidupan pada jaman itu antara alam dan penghuninya suka saling membantu dan memberi. Namun tetap pada porsinya sebagai manusia atau makhluk-makhluk halus. Manusia sebagai makhluk yang paling tinggi derajatnya tidak ada keinginan untuk menundukan alam. Demikian sebaliknya manusia tidak mau ditundukkan oleh alam secara keseluruhan hidupnya. Padahal manusia dalam teori di atas sebagai makhluk yang dinamis, namun tetap manusia ditentukan oleh kondisi alam atau paling tidak menyusuaikan diri (adaptif) dengan alam dimana mereka berada. Akan tetapi hari ini kondisi seperti itu sangat langka, dan hanya orang-orang tertentu yang mampu menekuninya.

Pada tahun 1998 penduduk Banjar Jangu kondisi hidup harmoni dan seimbang antara manusia dengan alam lingkungan masih dijalankan, sehingga pementasan tari Sanghyang masih dipentaskan secara rutin. Tanpa atas dasar ditanggap oleh touris manca negara. Sehingga pada saat itu pementasan tari Sanghyang masih difungsikan sebagai, 1) melindungi penduduk dan tempat tinggal mereka agat tidak mendapat gangguan roh jahat atau kejahatan bersumber dari manusia; 2) agar tanaman pertanian dan perkebunan, serta hewan-hewan peliharaan mereka tidak diserang wabah penyakit dan menghasilkan panen yang baik.

\section{Fungsi Sosial}

Manusia merupakan mahluk sosial yang dalam hidupnya selalu berhubungan dengan manusia lainnya. Dalam hal ini manusia membentuk suatu masyarakat yang didalamnya mereka saling berinteraksi. Tingkah laku manusia merupakan suatu hal yang bersifat dipelajari. Dengan kata lain tingkah laku manusia merupakan hasil dari proses belajar; dalam hal ini proses belajar dari orang tua atau lingkungannya kepada seorang individu. Hasil dari proses belajar inilah yang sering disebut dengan kebudayaan. Secara garis besar, terdapat wujud kebudayaan yaitu kebudayaan sebagai ide, nilai atau norma, kebudayaan sebagai tingkah laku dan kebudayaan dalam suatu wujud benda. Ketiga wujud tersebut merupakan suatu yang terintegrasi dalam kehidupan manusia. Manusia mempunya ide, nilai ataupun norma yang diwujudkan dalam tingkah laku, sedangkan tingkah laku tersebut menghasilkan barang-barang yang nampak nyata dan dapat diraba.

Berbagai macam definisi tentang kebudayaan dikemukakan para ahli kebudayaan dari berbagai bangsa. Kluckhohn mendefinisikan kebudayaan sebagai : (1) "Keseluruhan cara hidup suatu masyarakat", (2) "Warisan sosial yang doperoleh individu dari kelompoknya"” (3) "Suatu cara berpikir, merasa dan percaya", (4) "Suatu abstraksi dari tingkah laku", (5) "Suatu teori dari pihak antropologi terhadap suatu kelompok masyarakat nyatanya bertingkah laku", (6) "Suatu gudang untuk mengumpulkan hasil belajar", (7) "Seperangkat orientasi-orientasi standar pada masalah-masalah yang sedang berlangsung", (8) "Tingkah laku yang dipelajari", (9) "Suatu mekanisme untuk penataan tingkah laku yang bersifat normatif", (10) "Seperangkat tekhnik untuk menyesuaikan baik dengan lingkungan luar maupun dengan orang-orang lain", (11) "Suatu endapan sejarah" (Geertz, $1992: 4-5)$. Lebih lanjut Geertz -- dengan mengambil ide pemikiran dari Max Weber yang menyatakan bahwa manusia adalah seekor binatang yang tergantung pada jaringan-jaringan makna yang ditenunnya sendiri - menganggap kebudayaan sebagai jaringan-jaringan itu dan analisis atasnya lantas tidak merupakan sebuah ilmu eksperimental untuk mencari hukum malainkan sebuah ilmu yang bersifat intepretatif untuk mencari makna (Geertz, ibid, hal. 5). 
Beranjak dari pemikiran tentang kebudayaan tersebut, Geertz menawarkan cara menafsir kebudayaan dengan cara memaparkan konfigurasi atau sistem simbol-simbol bermakna secara mendalam dan menyeluruh. Mengingat bahwa simbol budaya adalah kendaraan pembawa makna, Geertz berkesimpulan bahwa selama ini simbol-simbol yang tersedia di kehidupan, namun sebuah masyarakat sesungguhnya menunjukkan bagaimana para warga masyarakat yang bersangkutan melihat, merasa, dan berpikir tentang dunia mereka dan bertindak berdasarkan nilai-nilai yang sesuai. Bagi Geertz, kebudayaan adalah semiotis yaitu, hal-hal yang berhubungan dengan simbol-simbol yang tersedia di depan umum dan dikenal oleh masyarakat yang bersangkutan. Simbol adalah sesuatu yang perlu ditangkap (ditafsir) maknanya dan pada giliran berikutnya dibagikan oleh dan kepada warga masyarakat dan diwariskan kepada anak cucu (Susanto, 1992 :vi-vii). Simbol yang paling mendasari dari keberadaan tari Sanghyang yang ada di Banjar Jangu yang diceritakan kelahirannya berdasarkan mitos-mitos yang diceritakan oleh para tetua, dan bukti fisik pura Ida Bhatara Gede yang masih berdiri megah di tengah-tengan Banjar Jangu. Walaupun mitos tersebut didapat dari mulut kemulut kayakinan masyarakat Banjar Jangu tidak terlalu berubah. Karena itu fungsi social pementasan tari Sanghyang yaitu, 1) untuk menata tatanan hidup akrab, harmonis, selaras antar warga dapat dipelihara, 2) pelanggaran sikap tidak etis dari warga menjadi sangat berkurang. Karena ada kondisi secara moral, masyarakat telah mendapat kekuatan mental spiritual saat melaksanakan ngoncang, music kulkul bambu dibawa berkeliling selama sebulan, kemudian Dewi Sri memberi berkah kekuatan untuk menghadapi tantangan.

\section{Makna Pementasan Tari Sanghyang}

Makna adalah mengandung arti yang sangat penting dalam kehidupan manusia. Bahkan tidak sedikit yang mengartikan makna dalam kehidupan manusia sebagai tujuan akhir dari suatu program maupun aktivitas hidup. Hidup tanpa makna bukan kehidupan manusia namanya. Karena itu tidak mengherankan bahwa manusia pada hakekatnya sebagai mahluk yang hidupnya senantiasa memproyeksikan makna dalam alam lingkungan tempatnya berada. Berkenaan dengan itu, manusia akan memberi makna kepada benda-benda; kemudian menumbuhkan nilai kepada benda-benda atau bentuk lainnya, serta menciptakan tata susunan pengertian yang luas. Kecendrungan memberi makna maupun nilai tersebut merupakan kegiatan kolektif yang dilakukan secara bersama-sama oleh kelompok masyarakat sesuai lingkungan yang dihadapi.

Gidden, mengabstraksikan hasil pikiran kelompok masyarakat dan selanjutnya hasil itu berupa konsep akan menata kembali kehidupan anggota masyarakat yang bersangkutan sebagai nilai budaya. Dengan kata lain, nilai budaya merupakan abstraksi dari segala sesuatu yang dianggap bermakna dan bernilai tinggi dalam kehidupan suatu masyarakat (2000). Karena nilai budaya sifatnya abstrak, berada di alam pikiran kepala-kepala manusia, berada dalam alam pikiran dari warga masyarakat dimana kebudayaan yang bersangkutan hidup. Nilai-nilai budaya ini juga sering disebutkan sebagai adat tata kelakuan yang berfungsi mengatur, mengendalikan dan memberi arah kepada kelakuan dan perbuatan manusia dalam masyarakat (Koentjaraningrat, 1990:5-6). Dalam pengertian ini nilai budaya juga dipakai untuk mengacu pada system pengetahuan dan kepercayaan yang disusun sebagai pedoman manusia dalam mengatur pengalaman-pengalaman dan persepsi mereka, menetukan tindakan dan memilih di antara alternative yang ada. Nilai budaya dalam pengertian ini dimaksudkan sebagai pola untuk/bagi perilaku (patten for behavior) kelompok social tertentu Dengan demikian, pemberian arti terhadap suatu benda, selanjutnya pemberian arti menjadi pemberian nilai budaya, juga mengandung pengertian pemberian makna. Hal ini akan menduduki posisi sentral dan paling dalam, dalam kerangka suatu kebudayaan, karena berfungsi sebagai pedoman tertinggi bagi tata kelakuan manusia.

Dalam masyarakat yang masih tradisional, menurut Berger (dalam Damardjati Kun Marjanto, 2003); (Purna, 2012), makna itu diberikan kepada manusia oleh tradisi yang jarang atau tidak pernah dipertanyakan. Apalagi makna maupun nilai budaya yang merujuk pada prinsip - prinsip moral, tujuan dan standar yang dianut oleh individu, klas social, atau masyarakat. Namun dewasa sekarang apakah penilaian seperti ini masih ajeg. Generasi tua mungkin masih. Bagi generasi penerus (muda) tidak sedikit yang mempertanyakan. Seperti pada masyarakat Banjar Jangu generasi mudanya tidak banyak yang tahu, apalagi menguasai tentang Tari 
Sanghyang dan perangkatnya. Lebih-lebih dalam rangka memaknai Tari Sanghyang secara makna fungsional yang memberi penekanan pada pentingnya kegunaan benda-benda kebudayaan, maupun makna simbolik yang penekanannya pada unsur estetis benda-benda kebudayaan dengan kualitas cita rasa, (Tester, 2003:5).

Hasil wawancara selama di lapangan, terutama kepada generasi tua yang dijadikan nara sumber tentang sikap dan pandangan terhadap ke-17 Tari Sanghyang yang ada di Banjar Jangu, masih sangat positip. Mereka yakin dan percaya bahwa dengan pementasan tari Sanghyang sudah mengandung standar moral masyarakat yang bersangkutan. Masyarakat generasi tua sangat mendukung agar tari Sanghyang dipentaskan kembali secara berkala maupun pada saat dibutuhkan. Hanya saja tempat pementasannya seperti lapangan yang luas pada saat observasi sedang dirintis, dan beberapa generasi muda sudah diadakan pendekatan untuk mau belajar gending maupun menjadi penari Sanghyang. Karena Tari sanghyang tidak saja sebagai tarian hiburan untuk para bhuta kala, maupun penolak atau mengusir penyakit dengan membangkitkan emosi keagamaan para pendukungnya, namun dengan adanya pementasan Tari Sanghyang dapat pula membangun solidaritas social, kerukunan masyarakat Banjar Jangu, serta membangun harmonisasi terhadap lingkungan alam. Karena alam bagi umat Hindu diibaratkan simbol Sanghyang Widhi (Tuhan). Menghormati alam berarti menghormati Sanghyang Widhi. Semua yang ada di alam ini adalah ciptaan Sanghyang Widhi. Karena itu tidak mengherankan Tari Sanghyang tergolong tari sakral (wali). Karena teknik mewujudkanya melalui kerawuhan/kerasukan (trance), sehingga sangat wajar masyarakat memberi penilaian, bahwa Tari Sanghyang memiliki makna maupun nilai religius magis yang tinggi. Dengan mementaskan maupun mempersembahkan Tari Sanghyang masyarakat sudah melakukan upacara (yadnya), sebagai ucapan rasa syukur kepada Sanghyang Widhi.

Tari Sanghyang dapat digolongkan tari sakral (wali) dapat diperkuat dari batasan-batasan yang dimilikinya, seperti para penarinya, terutama Sanghyang Dedari penarinya harus anak-anak remaja yang belum pernah datang bulan (bajang). Hal ini mengisyaratkan bahwa pelaku Tari Sanghyang Dedari diasumsikan betul-betul masih suci, dianggap pikiran dan raganya belum terkontaminasi oleh nafsu, apalagi nafsu yang menyesatkan (Sudarma, 2015). Darah yang keluar dari rahim manusia disimbolkan nafsu kotor.

Nilai kesederhanaan yang dimiliki oleh Tari Sanghyang dapat diamati dari kostum dan kata-kata lagu (gendingnya). Kostum Tari Sanghyang sangat berbeda dengan tarian tradisi Bali lainnya. Pakaian Tari Sanghyang sangat berkaitan dengan apa yag disediakan oleh alam. Karena lahirnya Tari Sanghyang sangat berkaitan fenomena dan isi alamya itu sendiri. Dan sangat berkaitan pula dengan hidup dan kehidupan manusia itu sendiri. Kata-kata pada gending Tari Sanghyang sangat sederhana dan mudah dipahami oleh masyarakat. Gending pada tari Sanghyang tidak menggunakan bahasa tinggi.

Penyelenggaraan pementasan Tari Sanghyang pada intinya persembahan terhadap para Dewa dan para Bhuta Kala. Manusia tugasnya menyeimbangkan kembali antara kedua kekuatan itu. Alam bhur (dewa/atas) dan alam swah (bhuta kala/bawah) harus diseimbangkan oleh alam bhuah (tengah/alam manusia) sebagai mahluk tertinggi yang memiliki bayu, sabda dan idep. Pementasan Tari Sanghyang di Banjar Jangu dalam rangka menyeimbangkan kembali kehidupan manusia dengan alam lingkungan, baik lingkungan social maupun lingkungan fisik. Manusia yang sakit agar segera sembuh, tanaman yang ada penyakitnya setelah ada pementasan Tari Sanghyang segera sirna dan hasil pertanian dan perkebunan berhasil baik. Kesederhanaan baik gerak tari, kostum, kata-kata, ritme, melodi, dalam rangka untuk mewujudkan suasana sejuk, hening, haru, khidmat. Kondisi gending pada Tari Sanghyang seperti itu dimaksudkan agar penari Sanghyang cepat menghadirkan roh. Kondisi seperti ini sudah menjadi harapan oleh masyarakat Hindu di Bali maupun di luar Bali. Dalam bentuk nyanyianpun banyak nyanyian dengan ucapan yang liriknya mengundang spirit, seolah olah para Dewa hadir di saat upacara maupun pementasan. Mandra Aryasa, (1993), mengemukan bahwa banyak alat music maupun melodinya berfungsi dalam upacara, tekanan-tekanan kendang, ritme, melodi dapat mengubah suasana menjadi sejuk, meriah, megah, agung, haru, khidmat atau semangat yang tinggi. 


\section{PEMBERDAYAAN TARI SANGHYANG DI BANJAR JANGU}

Usaha-usaha pemberdayaan terhadap Tari Sanghyang dilakukan dengan mengembalikan komunitas lokal untuk menjadi diri mereka sendiri dengan mempertahankan nilai-nilai budaya yang telah mereka miliki (Made Dyah Indira, 2009). Kevakuman pementasan Tari Sanghyang beberapa tahun lamanya mulai disikapi secara serius setelah diadakan penelitian oleh Balai Pelestarian Nilai Budaya Bali tahun 2016. Langkah-langkah yang sudah dan akan dilakukan sebagai berikut :

\section{1) Pemberdayaan Melalui Dimensi Struktur.}

Pemberdayaan melalui dimensi struktur adalah pola-pola organisasi yang mantap, dan stabil serta mampu meneruskandiri (self reproducing). Seseorang atau kelompok komunitas yang lahir dari berbagai struktur social, atas ketakutan sendiri ia tidak mampu untuk menguasai atau mengubah struktur itu (Soedjatmoko, 1983 : 157). Contonya, ada seseorang atau sekelompok (komunitas) yang tidak mampu menyamai komunitas lain dalam bidang pelestarian terhadap budaya yang hampir maupun sudah punah yang disebabkan ketidaktahuan informasi meminta bantuan maupun dukungan, baik bantuan material atau dukungan moral, atau dukungan regulasi, sehingga unsur budaya komunitas tersebut mengalami kepunahan. Padahal ada jalur biro krasi/pemerintah (struktur sosial) yang harus hadir di tengah-tengah komunitas tersebut. Pemerintah dewasa sekarang diwajibkan memfasilitasi untuk kebertahan budaya. Pemerintah Kabupaten Karangasem akan mengembalikan tempat pementasan Tari Sanghyang berupa tanah lapang yang tadinya dipakai untuk membangun sekolah. Karena tempat pementasan Tari Sanghyang, terutama Tari Sanghyang Jaran memerlukan pementasan yang cukup luas. Demikian pula Balai Pelestarian Nilai Budaya Bali ikut memfasilitasi untuk membeli pakaian sekeha gending atau sekeha tandak Tari Sanghyang. Pemerintah Kabupaten semestinya selalu mengagendakan pementasan Tari Sanghyang, namun Tari Sanghyang yang sifatnya sekuler. Pementasan yang tidak dilengkapi dengan sesajen sebagai mana mestinya dan presedur yang ideal. Hal ini untuk pengenalan pengetahuan tentang gending dan Tari Sanghyang kepada masyarakat luas, terutama kepada para generasi penerus.
Para generasi penerus sebaiknya diwajibkan untuk mengenal gending-gending maupun gerak Tari Sangyang.

Organisasi tradisional Desa Adat maupun Banjar Adat sebaiknya dilibatkan dalam pemberdayaan Tari Sanghyang. Karena lembaga seperti Desa Adat maupun Banjar adat merupakan lembaga tradisonal yang sudah mapan, stabil keberadaanya. Bahkan sudah memiliki sifat yang dinamis, kreatif dan adaptif terhadap perkembangan kemajuan bangsa (I Made Purna, 2000 : 35).

\section{2) Pemberdayaan Tari Sanghyang Melalui Dimensi Kultural.}

Model pemberdayaan yang dikemukan di atas lebih menekankan model pemberdayaan yang datangnya dari luar. Pemberdayaan yang datang dari luar keberadaannya kurang langgeng dengan kata lain proses pembangunan dari atas akan mematikan vitalitas dari bawah. Untuk itu perlu disadari, bahwa vitalitas yang tadinya sudah terbukti mempunyai kekuatan perlu dibangkitkan kembali. Perlu disadari, bahwa vitalitas Banjar Jangu dipulihkan kepercayaannya dan penonjolan daerahnya yang sudah menjadi kekhasnya. Kekhasan itu biasanya impuls-impuls yang paling dalam dan biasanya dipakai sebagai alat menata kehidupan anggota masyarakatnya. Dengan kata lain merupakan pola bagi suatu kelakukan, sehingga corak khas lokal dapat dipulihkan (Soedjatmoko, 1984 :95).

Perlu dimotivasi, bahwa Banjar Jangu kekhasan yang menonjol karena pernah hidup tujuh belas Tari Sanghyang. Bila perlu diberi predikat penamaan banjar tersebut sebagai "Banjar Sanghyang", sehingga para generasi merasa tidak asing mendengar kata Sanghyang itu sendiri. Demikian pula gending-gending diajarkan sedini mungkin kepada anak-anak sehingga kata-kata yang tersurat pada masing-masing gending Sanghyang tidak asing baginya. Semuanya ini bisa dibangkaitkan melalui " etos kebersamaan". Hubungan yang didasarkan perasaan bersama (consiuness colletive's) yang biasanya sudah terkemas ke dalam prinsip hubugan dekat yang bertatwam asi yang dipayungi oleh unsur kepercayaan yang sudah terwariskan berupa pura Pelinggih Ida Bhetara Gede. 
Sikap kultur hormat dan menghargai peran yang melekat kepada seorang yang disucikan perlu dibangkitkan kembali, seperti peran yang disandang oleh para penari Sangyang. Seorang penari Sanghyang bisa menari Sanghyang bukan karena proses belajar. Melainkan karena "nyungsung" dan "Ngayah". "Nyungsung", yaitu, menjunjung, menyembah, memuja. Umumnya yang disungsung dewa-dewi, maupun raja. Setelah menyadari ada yang disungsung tentu harus mampu memerankannya siapa yang disungusung. Termasuk memerankan fungsi dari dewa atau roh halus yang di"sungsung". Sikap atau perilaku, gelagat yang disungsung tidak bisa dipelajari, melainkan otomatis dalam bentuk kerawuhan/kerasukan (trance). Orang yang memerankan junjungan umumnya dipilih dan ditetapkan (kecatri) secara gaib. Karena itu tidak mengherankan kalau yang dipilih itu tidak canggung atau ragu untuk "ngayah", yaitu melakukan pekerjaan maupun peran tanpa upah. (Kamus Bali-Indonesia, 1993). Sanghyang Jaran misalnya, yang memakai simbolis binatang kuda (jaran), diaman seorang penari kerasukan di bawah pengaruh binatang jaran. Penari menunggang seekor kuda yang terbuat darui anyaman bamboo dan menyepak-nyepak bara batok kelapa. Keberanian menyepak-nyepak bara batok kelapa tentu diakibatkan oleh kekekuatan religius magisnya. Demikian pula Sanghyang Dedari. Yang menjelma jadi penari Sanghyang Dedari harus orang yang masih suci. Peran-peran seperti ini pemberdayaannya sebaiknya melalui membangkitkan dimensi kulturnya. Karena kultur seperti ini adalah kultur kekhasan, dan kebanggaan.

\section{SIMPULAN}

Tari Sanghyang, merupakan bagian dari Sembilan Tari Tradisi Bali yang telah mendapatkan pengakuan dan penetapan oleh Unesco (Badan Dunia Bidang Pendidikan dan Kebudayaan), tanggal 2 Desember tahun 2015, untuk mempertahankan eksistensi nya perlu dilakukan langkah evaluasi dan antisivasi. Untuk mendukung langkah tersebut diperlukan program kebijakan penelitian untuk mendokumentasikannya dan membuat kebijakan untuk pemberdayaannya. Menjaga keberadaan Tari Sanghyang dipandang perlu mengingat Tari Sanghyang telah memiliki fungsi religius-magis, fungsi social dan kearifan terhadap lingkungan alam serta memiliki makna, baik makna moral, solidaritas, kebersamaan, kerukunan maupun keharmonisan bagi masyarakat pendukungnya. Tari Sanghyang juga merupakan sumber taksu tari tradisi Bali, karena tari ini keberadaannya sangat tergatung kepada spirit dari pendukungnya. Nilai religius-magis masyarakat pendukunya perlu dipertahankan melalui pemberdayaan dimensi struktur dan kultur. Atas dasar model usulan pemberdayaan yang disampaikan ke masyarakat Banjar Jangu, maka tempat pementasan Tari Sanghyang sudah mendapat ijin dengan menggunakan tempat pengbongkaran sekolah Sekolah Dasar, perlengkapan menari sudah diadakan seperti gongseng, asep, majegau, pelawa, pakaian tari, kostum juru gending, sehingga pada malam hari tanggal 14 Februari 2017, dipentaskan Tari Sanghyang bersamaan dengan upacara mecaru atau masegeh.

Pemerintah dan masyarakat sebaiknya memprioritaskan program untuk menghidupkan kembali terhadap seni-seni yang hampir maupun yang sudah punah dengan memfasiltasi berupa Bantuan Sosial (Bansos). Jika hanya menghadalkan dari kemampuan dana organisasi maupun masyarakat pendukungnya sangat sulit. Lebih-lebih ada persepsi di masyarakat, kalau seni yang tidak bisa "dijual" akan dikesampingkan.

\section{DAFTAR RUJUKAN}

Aryasa, I Wayan Mandra. 1993. Seni Sakral. Jakarta : Dirjen Hindu-Budha dan Universitas Terbuka.

Dibia, I Wayan., dkk. 1999/2000. Tari Wali, Sanghyang, Rejang, Baris. Dinas Kebudayaan Provinsi Bali.

Dinas Pengajaran Daerah Tingkat I Bali. 1993. Bali Kamus Bali-Indonesia. Editor : I Wayan Warna.

Geertz, Clifford. 1992. Tafsir Kebudayaan, Terjemahan Francisco Budi Hardiman. Yogyakarta. Kanisius.

Gidden, Anthony. 2000. Anthony Gidden Suatu Pengantar. Terjemahan Henrry - Priyono. Kepustakaan Populer Gramedia. Yogyakarta. 
Indira, Made Dyah. 2009. Resistensi Masyarakat Terhadap Penguasa dan Pengusaha di Nusa Ceningan 1999-2008 (Studi Kasus Proyek Green Island). Skripsi S1 Jurusan Sejarah Fakultas Sastra dan Budaya, Unud.

Kaplan, David dan Albert A. Manner, 1999. Teori Budaya. Penerjemah Landung Simatupang. Yogyakarta : Pustaka Pelajar.

Koentjaraningrat. 1997. Teori Antropologi II. Jakarta : UI Press

Marjanto, Damardjati Kun, dkk. 2003. "Nilai Budaya dan Fungsi Upacara Pesta Ponan di Desa Poto, Kabupaten Sumbawa". Dalam Jurnal Penelitian Sejarah dan Nilai Tradisional. No. 08/III/2003. Balai Kajian sejarah dan Nilai Tradisional Denpasar.

Michael Pichard, 2006. Bali Pariwisata Budaya dan Budaya Pariwisata. Jakarta :Kepustakaan Populer Gramedia.

Marinis, Marco, 1993. The Semiotics of Perpoimence, Transleted by Aine O'Healy Blomomington and Indianapolis : Indiana Univerfsity Press.

Murdiyati, Y. 2009. "Seni Pertujukan Ritual Dalam Upacara Labuhan di Parangkusuma". Jurnal Seni Budaya Mudra. Vol 24. No 1. Januari 2009.

Nuryahman, dkk. 2015. Inventarisasi Perlindungan Karya Budaya Tari Tandak Gerak Provinsi Nusa Tengggra Barat. Denpasar : Balai Pelestarian Nilai Budaya Bali.

Purna, I Made. 2000. "Pemberdayaan Masyarakat Miskin di Kabupaten Badung". Jurnal Jnana Budaya, Media Informasi dan Publikasi Sejarah dan Nilai Tradisional. Edisi ke-4, No. 04/IV/2000. Denpasar: BKSNT Bali, Ditjenbud, Kemendikbud.

Purna, I Made. 2012. Pesta Ponan, Kearifan Lokal Masyarakat Samawa. Yogyakarta : Penerbit Ombak.

Panji I G. B. N. dan I Made Bandem. 1979. Ensiklopedi Musik dan Tari Bali. Yogyakarta : Kanisius.

Putra, Agung, A.A. Gde. Cudamani Tari Wali, tt.
Putra, Sudharma Ketut. 2015. "Tari Sanghyang Janger Maborbor di Desa Yang Api, Kecamatan Tembukuy, Kabupaten Bangli”. Jurnal Jnana Budaya. Vol. 20.No. 1. Februari 2015. Denpasar : Balai Pelestarian Nilai Budaya Bali.

Raka, I Dewa Gede dkk., Deskripsi Tari Sanghyang Desa Jangu Karangasem Bali. Denpasar : Departemen Pendidikan dan Kebudayaan, Kantor Wilayah Provinsi Bali, Bidang Kesenian , Bagian Proyek Pembina Kesenian Bali.

Santosa, Dwi Bambang I Made Dharma Suteja, I Made Purna, I Made Suarsana, Raj Riana Dyah Prawitasari. 2016. Kajian Tari Sanghyang di Banjar Jangu, Desa Duda, Kecamatan Selat, Kab Karangasem. Balai Pelestarian Nilai Budaya Bali. Penerbit : Kepel Press.

Sudarma, I Wayan. 2015. "Tari Sanghyang Gandrung Tradisi Sakral Masyarakat Sidetapa Kecamatan Banjar Kabupaten Bulelelng”. Jurnal Jnana Budaya. Vol. 20. No. 2. Agustus 2015. Denpasar: Balai Pelestarian Nilai Budaya Bali.

Sanderson, Stephen K. 2000. Makro Sosiologi, Sebuah Pendekatan terhadap realitas Sosial. Jakarta : PT. Raja Grafindo Persada.

Soemarwotto, Otto. 1997. Ekologi Lingkungan Hidup dan Pembangunan. Jakarta : Djambatan.

Susanto, Budi, S. J. 1992. "Sekapur Sirih". Dalam Clifford Geertz, Tafsir Kebudayaan. Yogyakarta : Kanisius.

Tim Peneliti, 1984/1985. Pemeliharaan dan Pemanfaatan Kesenian, Naskah Pendokumentasian Tari Sanghyang Desa Jangu Perbekalan Duda, Kecamatan Selat, Kabupaten Karangasem. Denpasar : Proyek Pengembangan Kesenian Bali, Direktorat Jenderal Kebudayaan Depdikbud.

Tim Peneliti, 2002. Hasil Penelitian Tari Sanghyang di Banjar Jangu Desa Duda Kecamatan Selat, Kabupaten Karangasem. Denpasar: Dinas Kebudayaan Provinsi Bali.

Taster, Keith. 2003. Media Budaya dan Moralitas. Terjemahan. Yogyakarta : Juxtapose bekerjasama dengan Kreasi Wacana, Jogyakarta. 